\title{
Determinants of Access to Formal Financial Sources of Micro and Small Enterprises (MSEs) in West Oromia Region, Ethiopia
}

\author{
Deresse Mersha ${ }^{1}$, Zerihun Ayenew ${ }^{2}$ \\ ${ }^{1}$ Department of Accounting and Finance, Jimma University, Jimma, Ethiopia \\ ${ }^{2}$ Department of Management, Jimma University, Jimma, Ethiopia \\ Email address: \\ deresmersha@gmail.com (D. Mersha), zabirbirsa@yahoo.com (Z. Ayenew)

\section{To cite this article:} \\ Deresse Mersha, Zerihun Ayenew. Determinants of Access to Formal Financial Sources of Micro and Small Enterprises (MSEs) in West \\ Oromia Region, Ethiopia. International Journal of Business and Economics Research. Vol. 6, No. 5, 2017, pp. 100-110. \\ doi: 10.11648/j.ijber.20170605.13
}

Received: May 5, 2017; Accepted: May 20, 2017; Published: September 25, 2017

\begin{abstract}
Ethiopian MSEs are at early stage of development and face various constraints. One of the most crucial problems is financial constraint for start-up and operational activities. In order to promote MSEs as engines of growth, it is essential to understand the bottlenecks surrounding MSEs' access to finance. The main objective of this study is therefore to identify factors enabling successful access to formal financial sources. 200 sample MSEs selected from three towns in west Oromia region are used for this study. The finding indicated that; availability of collateral, MSE's age, Sector of the MSEs, Legal ownership, owner's or manager's age, owner's or manager's religion and Size of the MSE significantly determine access to bank credit at $\mathrm{p}<0.1$. It was also found that Keeping accounting record, Sector, Legal ownership, owner's or manager's age, owner's or manager's business experience and Size of the MSE significantly determine access to credit from MFIs at $\mathrm{p}<0.1$. From supply side, high interest rate and long loan procedures are the main factors. This implies that though MFIs are established to provide credit to MSEs, the system of credit provision is almost similar with banks.
\end{abstract}

Keywords: Access to Finance, Determinant Factors, Micro and Small Enterprises, Formal Financial Institutions

\section{Introduction}

MSEs have been recognized as being great contributors to the Ethiopian economy offering both employment and platform for innovative ideas. They form a larger percentage of the businesses that operate in the country as compared to their medium and large counterparts. They are however challenged by many constraints that hinder their performance and consequently their growth. One of the main constraints that have been highlighted over the years is lack of finance.

The impediments to MSEs' access to finance arise both from the demand side and supply side. The possible reasons for finance problems among others may be related to the poor management skills of the owner/manager, insufficient capital invested by the owner, an over-reliance on external borrowings [9]. The inefficient use of accounting information to support their financial decision-making and the low quality and reliability of financial data are part of the main problems of MSEs [11].

To alleviate the financial problems of MSEs, Ethiopian government is supporting the sector by encouraging Micro Finance Institutions (MFIs) to expand to the rural areas, creating favourable environment for banks to expand their branch to regional cities, introducing capital good finance companies. In addition, the government is also trying to give training on how to keep accounting records and financial management, mainly for those found in major urban centres. Despite these efforts of the government, MSEs are still complaining about lack of access to finance as their critical problem.

The authors have undertaken a survey research on the topic "Financing Micro and Small Enterprises: Evidence from West Oromia Region, Ethiopia" in the academic year $2015 / 16$. The objective is to identify the bottlenecks surrounding MSEs in the country and provide appropriate suggestions for solving them. This article is part of the above 
mentioned study specifically aimed to identify the main determinant factors that significantly influence access to finance of MSEs taking evidence from least developing country, Ethiopia. Specifically, the evidence for the study is taken from MSEs in three towns in west Oromia sub-region. To achieve the purpose, the remaining part of this paper is structured as follows: Section two explains the research problem, section three reviews related literatures, Section four presents the research design and methodology adopted in the study, Section five presents the result, analysis and discussion and finally section six concludes the paper.

\section{Statement of the Problem}

Challenges of MSEs' access to finance may either come from supply side or demand side. From the supply side, the lending institutions may refrain from MSE funding due to fear of default, generally bracketing MSEs sector as high risk endeavour or from information asymmetry that happens to be experienced at a higher level in MSEs sector. On the other hand, the demand side may be due to the entrepreneur lack of proper information, lack of business networking or business skills. In addition, firm's, financial and entrepreneurial characteristics have been highlighted in many researches as the main factors that influence MSEs' access to funding. Financing choices of MSEs are influenced by the preferences of each firm's entrepreneur and more importantly by the options that are available to them, In what form, from whom, how successfully and at what cost small firms are financed thus depends on wide range of factors both internal and external to the firm.

Despite all these efforts, many research outputs conducted in Ethiopia indicates that access to finance is still the bottleneck for MSEs. On the other hand, to our knowledge, there are few studies that investigated the significant factors that determine financing options of MSEs. Specifically, the status of the problem in west Oromia sub-region including Jimma, Illu Aba Bora and the four Wellega zones are rear. Though some exist, most of them focus on general problems of MSEs. They are short in depth and detail on many aspects of MSEs, including finance related issues. Although finance is not everything, enterprises need finance to invest in new equipment and machinery, reach out to new markets and products, and cope with temporary cash flow shortages as well as to innovate and expand. Therefore, the main objective of this study is to identify significant factors that determine access to finance of MSEs found in west Oromia sub-region.

This study is different from earlier other studies in the following respect. First, earlier studies focused on general constraints of MSEs, not on the specific functional areas. Investigating an issue focusing on a particular aspect will help to identify the real problem in depth. Second, this study tries to identify factors affecting access to finance both from demand side and supply side as opposed to earlier studies that focused mainly on the demand side factors. Finally, this study concentrates on west oromia sub-region where there are few studies undertaken.

\section{Literature Review}

Many studies tried to identify the reasons for financial problem in MSEs. For instance, Ssendaula listed factors that have discouraged banks from lending to MSEs [46]. Among them are poorly compiled records and accounts; low levels of technical and management skills; outdated technologies; lack of professionalism and networking; lack of collateral; lack of market outlets due to poor quality and non-standardized products; poor linkages and limited knowledge of business opportunities. According to Levitsky and Prasad the reasons why small enterprises have limited access to institutional finance are well known [29]. These are: (a) Lending to small enterprises is considered to be risky. The uncertainties facing small industry, the high mortality rate of such enterprises and their vulnerability to market and economic changes make banks reluctant to deal with them, and there is a parallel reluctance on the part of small-scale enterprises to borrow from banks. (b) Banks and financial institutions are biased in favour of lending to large corporate borrowers. In some countries there are links between banks and corporate borrowers that take the forms of joint directorships, joint ownerships, and various other joint financial dealings. (c) The administrative costs of lending to MSEs are high and cut deep into the profitability of such loans. (d) MSEs seeking loans are unable or unwilling to provide accounting records and other documents required by banks, or to provide securities or collateral for the loans.

In general, factors that affect access to finance of MSEs fall under owner's/manager's characteristics, MSE's characteristics and Supplier's characteristics as discussed below.

\subsection{Owner's Characteristics}

The personal characteristic of the owners/managers makes a difference to the firm's ability and likelihood of accessing external finance. The reason is that the owner/manager in MSE has the dominant position in the firm in their role as the primary decision maker. The followings are owner's/ manager's characteristics that affect the financing options of MSEs extracted from earlier researches.

\subsubsection{Owner's/Manager's Age}

It is often found that the personal financing preferences of entrepreneurs appear to change depending on age. According to Romano, Tanewski and Smyrnios, the effect of the owner's/manager's age on the financial behaviour of MSEs can be noted in that unlike younger entrepreneurs, older entrepreneurs are less likely to invest additional finance into their firms [44]. This finding is in line with that of Van der wijst who suggests that older MSE owners/mangers are more reluctant when it comes to accepting external ownership in the firm [51]. Further, Vos et al. examined MSE financial behaviour utilizing two data sets from the UK and the US consisting of 750 and 3, 239 MSEs, respectively. The results showed that younger owners/managers tend to use more bank overdrafts and loans, credit cards, own savings, and family 
sources than older owners who appear to be more dependent on retained profits [52]. Clarifying the connection between the financial growth cycle of MSEs and the owner's/manager's life cycle, Briozzo and Vigier stated as the firm and its owners/managers grow older, information asymmetries decrease, granting easier access to debt (a supply-side effect), while the owner's risk aversion and personal costs of bankruptcy increase with age, and thus he or she desires to use less leverage [10].

\subsubsection{Religion of the Owner/Manager}

Islam is the world's second largest religion. The principles of Islamic finance are universal which states, "you cannot make money out of money". No one can charge or pay interest, or invest in items that Islam forbids such as alcohol and gambling. As a result of this religious dogma, followers of Muslim religion rarely take credit from Banks and MFIs as most of the credits are interest bearing. In line with this, around a third of Ethiopians identify themselves as Muslim, making the country's Muslim population larger than that in Saudi Arabia, Syria or Yemen. Access to finance in Ethiopia is generally very low. Nationally, only 14 percent of the adult population has access to formal credit and savings products but this rate drops to one percent in rural areas. And, until recently, there were no financial institutions catering to the large population requiring Islamic-compliant products. Especially, in the regional towns like Jimma, where there are significant Muslim population, awareness about interest free banking is not popular.

\subsubsection{Entrepreneurship Capability}

MSE market entry behaviour significantly determines financing preferences. MSE owners who initiate their own businesses have implicit demand for further growth and better entrepreneurial character in raising finance from non traditional sources of capital [50]. There is some form of entrepreneurial continuum between voluntary and forced entrance conditions. Voluntary entrants have better entrepreneurial orientation than their forced entrant counterparts. Therefore, the degree of voluntary entrance can serve as proxy for the degree of entrepreneur ability. MSE owner who voluntarily started business has a relatively good deal of entrepreneurship behaviour and relatively higher preference for external financing schemes [20].

\subsubsection{Experience of the Owner/Manager}

Experience of the owner or manager affects access to finance both from the demand and supply side. Usually, experienced owners or managers seek to be stable and stay in one place for a long period of time. Hence, experienced owners or managers know how to get his/her financial needs. Creditors have also a great trust for stable borrower than unstable one. From the lender's perspective, as experienced entrepreneurs are believed to be better performers than less experienced entrepreneurs, it is then logical to factor experience into the process of evaluating the creditworthiness of MSEs.

There are several empirical evidences about the effect of experience on access to formal finance. Ayalew \& Gashu in their study in Dilla town in Ethiopia found that a significant number of loan request were rejected because of lack of experience by the owners or the managers [5]. Experience, as measured by the number of years in an industry, Cole found that it enhances the availability of credit [14]. In addition, other researchers found that the experience of the entrepreneur is one factor that explains the difference in external financing levels available to MSEs. They further explained that prior experience in the industry positively correlates with the share of external financing in the firm and added that the cumulative experience of the owner/manager plays a crucial role in overcoming some of the problems that hinder MSE access to external finance, including information asymmetry and moral hazard.

\subsection{MSE's Characteristics}

Firm level characteristics that are believed to affect access to finance of MSEs include age of the MSE, legal form of MSEs, ownership of collateralized asset, presence of formal accounting system, the size of the MSE and the sector in which the MSEs are engaged as discussed below.

\subsubsection{Age of the Firm}

Age of the firm is among the factors that determine firms' access to bank loan. The role of age in explaining disparities in financial access of firms is accentuated when the financial system accommodates relationship lending. In countries where banks attach recognition to the length of their relationship with borrowers, older firms with a longer relationship with lenders have an upper-hand in accessing loans [17]. This has been confirmed by Abor and Biekpe who find that older firms have a stronger relation with their bank or MFIs and hence a better access to bank credit compared with younger firms that have no or lesser ties with their financier [2]. According to Klapper, Sarria- Allende and Sulla, younger enterprises are more reliant on informal financing and far less on bank financing [27]. This is supported by Quartey who concluded the significant positive effect of firm age on the ability to access external finance [42]. In addition, in their investigation of the impact of firm and entrepreneurial characteristics on MSE access to debt finance in South Africa, Fatoki and Asah observed that MSEs established more than five years have a far better chance to be successful in their credit applications compared with MSEs established for less than five years [18].

Firm age has been widely recognized as a significant determinant of accessibility to financing in many studies because of the following reasons. First, as younger firms are usually characterised by informational opacity as a consequence of not having an established track record, this may lead to the reluctance of banks and other financial institutions to lend to these firms. That is young firms often face difficulties in obtaining external finance because of informational disparities. Second, age of firms might be a signal of experience and therefore probability of business failure or default is less. And finally, it is easier to monitor 
well-established firms where old firms are more likely to have access to bank finance or face less constraints [7].

\subsubsection{Legal Form of the Business}

According to Article 212 of the commercial code of Ethiopia, only six different forms of business organizations are recognized. These are ordinary partnership, general partnership, joint venture, limited partnership, private limited company and Share Company [15].

MSE owners that are established as either sole proprietorships or partnerships prefer to exhaust internal sources of finance before going for debt or equity because of the collateral incentives of financing institutions that have bearings on personal assets of the MSE owners thereby following the pecking order. On the other hand, for private limited companies, since investment risk is limited to the amount of capital contributed, owners prefer to choose financing options that could maximize firm value even if internal sources are not yet exhausted. In line with this Gebru found the probability that MSEs preferring external finance is 5.8 times higher for partnership businesses compared to sole proprietorship businesses. Similarly, the probability that MSEs established as private limited companies (PLCs), owners prefer external finance 8.9 times that of sole proprietorships. PLCs tend to finance operations of their business using financing mix that maximizes their firm value even if internal sources are not exhausted. However, MSEs owners with sole-proprietorship form of business prefer to exhaustively use the available internal sources of finance before going for external sources [20]. Coming to Ethiopia, Fanta's study reported that analysis of access to credit based on ownership form reveals that compared with sole proprietors, PLCs had a relatively better access to bank loan [17].

\subsubsection{Ownership of Collateralizable Assets}

Collateral plays a vital role in accessing bank loan. Many MSE owners complain that they are denied loan despite a strong earning capacity and future growth prospect. In Ethiopia, Fanta found that firms that own assets for collateral are found to have a relatively better access, signifying the importance of collateral in the credit market [17]. Collateral is a key element of credit contracts. It decreases the incentives of borrowers to default, increases the incentives to devote effort to the project, and decreases bankruptcy costs for banks. The possibility of using outside assets as collateral allows firms to maintain higher leverage ratios, which is particularly important for small firms.

As the provision of collateral plays an indispensable role in easing MSE access to debt finance, MSEs that have more fixed assets tend to utilise higher financial leverage. The reason for this is that these firms can borrow at lower interest rates as their loans are secured with these assets serving as collateral. In their investigation of the role of collateral and personal guarantees using a unique data set from Japan's MSE loan market, Ono and Uesugi found that a positive relationship between the use of collateral and the strength of the borrower-lender lending relationship results in easier
MSE access to external sources of finance [39]. A similar conclusion was reached by Odit and Gobardhun when examining the factors determining the use of financial leverage by MSEs in Mauritius. They concluded that access to debt finance is affected by the positive association between the debt ratio and the asset structure. Furthermore, they revealed that MSEs with a lower portion of tangible assets in their total assets are more likely to encounter difficulties in applying for outside finance because of the inability to provide the collateral required [37].

\subsubsection{Formal Accounting}

Without adequate, effective and timely financial reports and analysis, the MSEs are losing the benefits from these practices such as improved monitoring of financial health and progress, improved ability to anticipate fortunes or failures, better assessments of financial risks and greater ease in financial planning and control. Most importantly, in the context of MSEs requiring extra capital to grow, regular financial reports can provide indications on their ability to produce steady cash flows and to service debt. It has been established that the use of appropriate financial reporting and management accounting practices could be one of the determinants of company survival particularly MSEs [36]. This will intern increase the credit worthiness of MSEs which means MSEs keeping formal accounting record will easily access credit facility.

Lending to small businesses can be seen to be time consuming and costly for banks and other financial intermediaries. Because such small firms lack proper accounting procedures and owners easily mix their business and personal finances, making their financial statements often unreliable. They may not have proper bookkeeping procedures, inventory systems, business plans or income statements making it hard for a bank to evaluate them [19]. According to Linder \& Hoelzl, half of Austrian MSEs use their financial statements often or very often to secure supplier credit or a bank loan [28].

MSE's lack of access to capital and high interest rates charged are partially the result of incomplete or no accounting records, and the inefficient use of accounting information. Poor record keeping and accounting information make it difficult for financial institutions to evaluate potential risks and returns, making them unwilling to lend to MSEs. As a result, MSEs pay high interest rates or fall back on the middlemen or moneylenders, whose loans are costly and often restrictive. The misuse and inaccuracy of accounting information causes MSEs to inaccurately assess their financial situation, and make poor financial decisions, as well as leads them to face high failure rate.

\subsubsection{Size of the MSE}

Even though there is no consensus amongst researchers about the criteria that should be employed to measure the size of the firm, the notion that firm size has an effect on MSE's activities and its potential to expand appears to receive general agreement. A firm's size is usually coupled with its age as they tend to have similar influence on the firm's life 
cycle. This influence can be strongly observed in the decision making process in the firm about whether one particular sort or another of finance should be chosen and utilized [14]. Studying firms financing and capital structure using a sample consisted of 292 Australian firms, Cassar concluded that larger firms rely on long-term debt and external financing including bank loans [14]. This is consistent with Storey who found that in the case of MSEs, the owner's/manager's personal savings are more important as a source of fund during the start-up stage than outside finance such as loans and overdrafts from banks [48]. From another angle, the extent to which firm size can impact the availability of finance to the firm was measured by Petersen and Rajan. They argued that as firms grow, they develop a greater ability to enlarge the circle of banks from which they can borrow. They then provided evidence that firms dealing with multiple banks and credit institutions are nearly twice as large as those with only one bank [41].

Other empirical evidences have also found the same result. For instance, Gebru found that compared to large firms, MSEs face a relative disadvantage to raise finance from formal institutions such as banks because they are considered to have higher financial risk [20]. Cassar argued that it may be relatively more costly for smaller firms to resolve information asymmetries with debt providers. Consequently, smaller firms may be offered less debt capital [13]. Beck, Demirgüç-Kunt, \& Maksimovic studied financing pattern of 3,000 firms of different sizes in 48 countries. Their results indicated that small firms rely more on internal and informal finance but less on bank finance than large firms [6]. Similarly, in a study of credit constraints in four African countries, Bigsten et al. suggested that firm size is a strong determinant in obtaining credit [8].

Mateev, Poutziouris, and Ivanov employed a panel of 3,175 MSEs in 7 European countries and found that small sized enterprises tend to use more short term bank loans and trade credit whereas medium sized enterprises use more long term loans and also have higher leverage, indicating that large enterprises may have more bargaining power over loan creditors [31]. Therefore, it is possible to conclude that firm's size and access to formal finance has a positive association.

\subsubsection{Sector in Which MSE Is Engaged}

A number of studies evidenced that factors related to the industry sector in which a firm operates also explain capital structure and financial decisions. Firms in the services sector, for example, can differ from those operating in manufacturing or construction in terms of financial needs and choices. Michaelas et al. empirically analysed the different capital structure determinants across time and industries utilizing a sample of 3,500 randomly selected MSEs across ten industries in UK. They summarised that the impact of industry on short-term and long-term debt varies greatly across industries [33].

There are many empirical evidences about the effect of sector on access to formal finance in the African content. For instance, the effect of industry classification on the capital structure of Ghanaian MSEs was examined by Abor \& Biekpe. The results of the study revealed some differences in the funding preferences of the Ghanaian MSEs across industries. MSEs in the agriculture sector and medical industries rely more on long-term and short-term debt than their counterparts in manufacturing. Abor \& Biekpe further concluded that short-term credit is more used in wholesale and retail trade sectors compared with manufacturing SMEs, whereas construction, hotel and hospitality, and mining industries appear to depend more on long-term finance and less on short-term debt [2]. In a study performed on MSEs in Zimbabwe, business sector in which the enterprise is operating was found to be a very important factor in accessing loans. Martin and Daniel found that the industry with which the business belongs was also found to have an implication on access to finance [30]. In terms of the tradeoff hypothesis, businesses with mostly tangible assets (like construction and manufacturing) should borrow more because of the collateral provided by their assets [24]. Generally, we can say that industry type affects access to formal source of finance.

\subsection{Supplier's Characteristics}

In general, there are several causes of credit problems for small firms as seen from suppliers' side: fixed lending costs, credit policy and location of Financial Institutions are some of them.

\subsubsection{Fixed Lending Costs}

Providing loans is an activity that causes important fixed costs associated with loan appraisal, supervision, and collection. This implies that the cost per birr lent is high for small loans to MSEs. As a consequence, banks or MFIs would have to charge higher interest rates on such loans to generate the required returns. In general, banks are unwilling to provide such unsecured loans in small amounts usually lent to microenterprises. MFIs can give the loan but the interest rate is too high and can discourage borrowers.

\subsubsection{Location}

The geographical area where a firm is located in the proximity of banks or MFIs is also believed to have an influence on the firm's ability to gain external finance. For example, MSEs located outside major cities face greater difficulties in acquiring external finance, especially longterm debt, compared with their counterparts operating in cities [3]. In the same regard, Fatoki and Asah added that the geographical location of MSEs close to their banks and MFIs advantages them in that they can better establish relationship. As a result, MSEs are better able to access loans using no more than soft qualitative information [18]. A study conducted by Okpara and Wynn reported poor location results in inaccessible businesses to both customers and suppliers as one of the reasons for MSE's failure in Nigeria [38]. Additionally, another study by Reddy examined the challenges and obstacles encountered by MSEs in Fiji. They found that in spite of the relatively high cost of rentals, MSE 
owners preferred to move their firms' activities to urban areas to escape the negative impact of the local environment features of rural areas on raising external finance, including poor local transportation and communications infrastructure, and consequently on the performance and growth of their firms which made their survival more difficult where such climate exists [43].

\subsubsection{Credit Policy of Financial Institutions}

All financial institutions have their own credit policy. This credit policy states the requirements and procedures of granting credit to borrowers. It is prepared under the general guideline of central banks of each country. It can be strict or easy based on the perceived risk of the financial institutions. When the credit policy is strict and involves so many procedures, borrowers are discouraged to request credit.

\section{Research Methodology}

Generally, the first step in any sampling method is to identify the study population from where the samples would be drawn. This is often undertaken by using lists of population where such lists are available; otherwise, we need to prepare the list and undertake the designed study based on the selected sampling strategy and size. Nevertheless, not only the population of MSEs is too large and their distributions across sectors and zones have been diverse, but also the records showing their lists were not available. With the limited research budget and time, the difficulty of preparing sampling frame was well understood. Hence, we decided to conduct the study in three major towns in west Oromia including Jimma, Nekemte and Metu towns. Therefore, the sample size for this study is determined to be 300 MSEs.

Once the sample size is decided, stratified sampling technique was applied to take representative samples from each sector. The final sample MSEs were selected using stratified random sampling from each group as follows. First, the list of these MSEs was collected from the respective towns MSE agency. Second, the organizations were stratified based on the five industry grouping and numbered sequentially and finally, the samples were selected using lottery method from each stratum in each city keeping the proportion of the industries the same as the one in the population.

To achieve the objective of the study, survey method was implemented to collect data using interview schedule. The schedule prepared in English at the beginning was later translated in to local language so that the respondents easily understand the questions. After refining and translating the questionnaire as mentioned above, the data for the research were gathered through interview by trained enumerators.

Tools for test of hypothesis and measures of association such as Bivariate analysis and multivariate analysis are used in the study. Specifically, Binory logit model were used to identify owners and MSEs related factors that determine access to formal credit from financial institutions. There are several methods to analyze the data involving binary outcomes. However, for this particular study, logit model was selected over other models. The analysis involves twelve variables, two of which are dependent and the remaining ten are independent. The two dependent variables, "access to bank credit" and access to MFI's Credit are reported by the respondents with a discrete scale of " 0 " and " 1 ", where " 0 " means not taken formal credit and " 1 " means have access to formal credit from Banks or Microfinance institutions. In addition to the two dependent variables mentioned above, other 10 independent variables are identified from earlier researches and used in the analysis. Table 1 below shows the ten independent variables, their symbols and how they are measured.

Table 1. Independent Variables and Their Measurement.

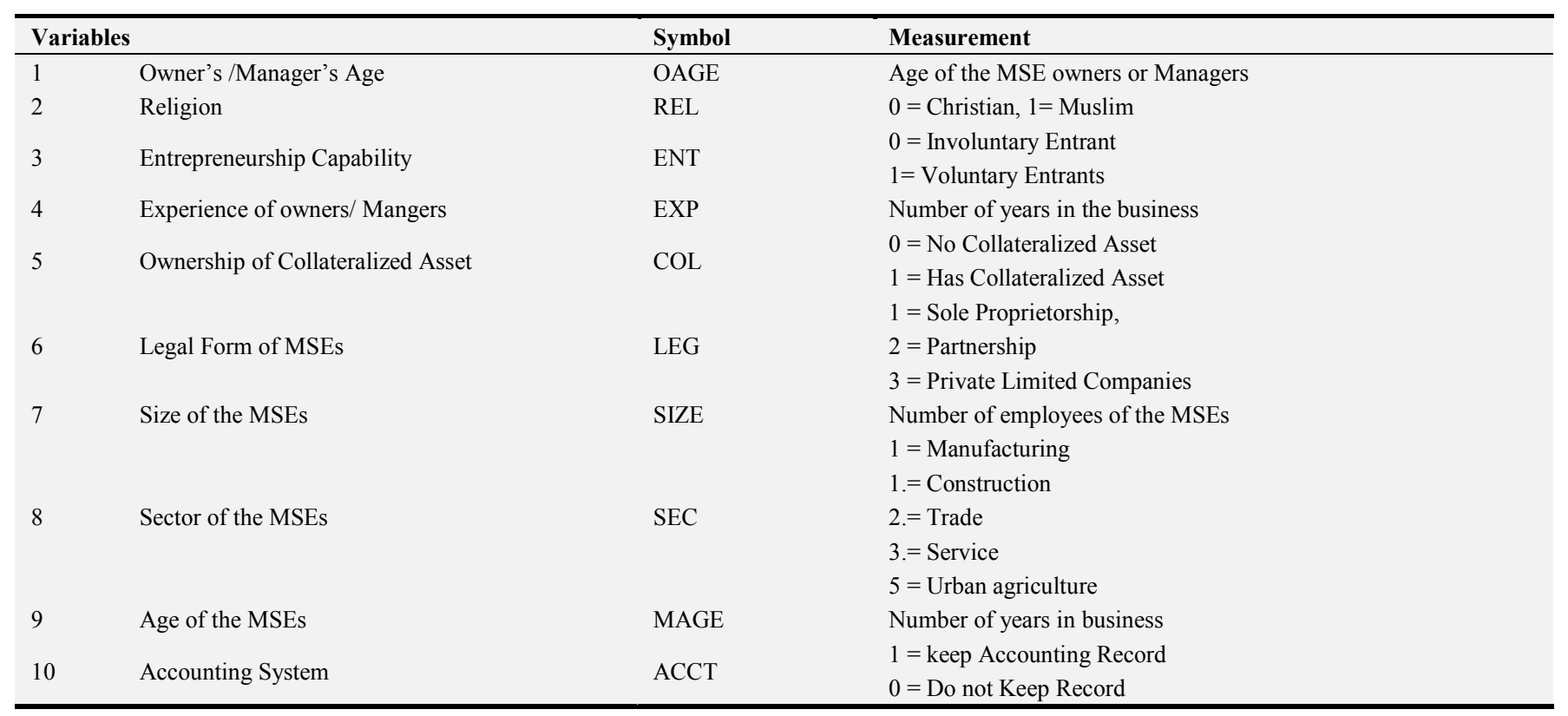


In order to identify factors determining access to formal credit, the general functional relationship among the dependent variable and the 10 independent variables can be given as follows.

Access to formal Credit $=\mathrm{f}(\mathrm{OAGE}, \mathrm{REL}, \mathrm{ENT}, \mathrm{EXP}, \mathrm{COL}$, LEG, SIZE, SEC, MAGE, ACCT)

Logit model is selected for this study because, the dependent variable "Access to formal Credit" is discreet in nature and have two values. The general logit model can be given as follows [21]

$$
Z_{i}=\beta_{0}+\sum_{j=1}^{n} \beta_{i} x_{i}+U_{i}
$$

Where $Z_{i}$ is the dependent variable with a value " 0 " when firm i have no access to formal credit and " 1 " when firm $i$ have access to credit, $x_{i}$ is a vector of explanatory variables and $U_{i}$ is the discrepancy term. Using the 10 independent variables and the general logit model above, the following logistic regression equation were used to empirically identify the determinant factors

$$
\begin{gathered}
\mathrm{L}_{\mathrm{i}}=\beta_{0}+\beta_{1} \mathrm{OAGE}+\beta_{2} \mathrm{REL}+\beta_{3} \mathrm{ENT}+\beta_{4} \mathrm{EXP}+\beta_{5} \mathrm{COL}+ \\
\beta_{6} \mathrm{LEG}+\beta_{7} \mathrm{SIZE}+\beta_{8} \mathrm{SEC}+\beta_{9} \mathrm{MAGE}+\beta_{10} \mathrm{ACCT}+\mathrm{u}_{\mathrm{i}}
\end{gathered}
$$

Where:

$\mathrm{L}_{\mathrm{i}}=\log$ of the odds ratio of having access to formal credit to not having access to credit

$\beta_{0}=$ the intercept of the regression equation

$\beta_{\mathrm{i}}=$ the coefficients of each independent variables

$\mathrm{u}_{\mathrm{i}}=$ the error term

\section{Result and Discussion}

As it was explained earlier, binary logistic regression is used to identify determinant factors that affect access to external formal financial sources. Binary Logistic regression does not make many of the key assumptions of multiple linear regression and general linear models that are based on ordinary least squares algorithms particularly regarding linearity, normality and homoscedasticity [49]. However, some other assumptions still apply which includes large sample size and multicollinearity. Therefore, these two assumptions were checked before the binary logistic regression is run.

Different authors tend to give different guidelines concerning the number of samples required for multiple regressions. Stevens recommended that for social science research, about 15 subjects per independent variable are required for a reliable result. That means, for ten independent variables used in this study, the minimum required sample size should be 150 (15x10) [48]. Tabachnick and Fidell further gave another alternative formula for calculating sample size required, taking into account the number of independent variables to be used: $\mathrm{N}>50+8 \mathrm{~m}$ (where $\mathrm{m}=$ number of independent variables)[49]. Applying this formula and using ten independent variables, the number of required samples should be a minimum of $130(50+8 \times 10)$. The 200 responses used in the study are well above the minimum needed under both formulas and satisfies sample size requirement for this specific study.

Another assumption is absence of multicollinearity which refers to the relationship among the independent variables. Since multiple regressions don't like multicollinearity, checking of this assumption is important before running regression analysis [40]. In order to check existence of multicollinearity problem, correlation coefficients among the variables were calculated and presented in a matrix as shown

\begin{tabular}{|c|c|c|c|c|c|c|c|c|c|c|c|c|}
\hline & ENT & ACCT & COL & MAGE & SEC & SIZE & LEG & OAGE & EXP & REL & BANK & MFI \\
\hline ENT & 1 & & & & & & & & & & & \\
\hline ACCT & .008 & 1 & & & & & & & & & & \\
\hline $\mathrm{COL}$ & .096 & $.185^{* *}$ & 1 & & & & & & & & & \\
\hline MAGE & -.113 & -.077 & $.326^{* *}$ & 1 & & & & & & & & \\
\hline SEC & -.066 & .041 & $.283^{* *}$ & $.292^{* *}$ & 1 & & & & & & & \\
\hline SIZE & .107 & $.284^{* *}$ & $.313^{* *}$ & $.339^{* *}$ & .115 & 1 & & & & & & \\
\hline LEG & $-.168^{*}$ & $.461^{* *}$ & .012 & -.020 & -.109 & $.251^{* *}$ & 1 & & & & & \\
\hline OAGE & -.036 & -.061 & $.295^{* *}$ & $.577^{* *}$ & $.293^{* *}$ & $.225^{* *}$ & -.097 & 1 & & & & \\
\hline EXP & -.006 & $-.167^{*}$ & $.178^{*}$ & $.722^{* *}$ & .067 & $.226^{* *}$ & -.036 & $.653^{* *}$ & 1 & & & \\
\hline REL & .037 & $-.415^{* *}$ & .074 & .050 & -.048 & $-.193^{* *}$ & $-.272^{* *}$ & .002 & .060 & 1 & & \\
\hline BANK & .074 & $.204^{* *}$ & $.308^{* *}$ & $.280^{* *}$ & .054 & $.462^{* *}$ & $.257^{* *}$ & $.247^{* *}$ & $.176^{*}$ & $-.152^{*}$ & 1 & \\
\hline MFI & .033 & $.261^{* *}$ & -.001 & -.067 & -.105 & -.033 & $.214^{* *}$ & .020 & -.087 & $-.155^{*}$ & -.014 & 1 \\
\hline
\end{tabular}
in the table 2 below.

Table 2. Correlation Matrix Among the Variables Under Study.

*. Correlation is significant at the 0.05 level (2-tailed). ${ }^{* *}$. Correlation is significant at the 0.01 level (2-tailed)

According to Pallet, multicollinearity exists when the independent variables are highly correlated $(\mathrm{r}>0.9)$. As it is shown in the correlation matrix presented in table 2 above, all the correlation coefficients among the variables are less than 0.9 which implies multicollonearity is not a problem
[40].

Once the assumptions were tested as shown above, binary logistic regression was run to identify which of the independent variables significantly determine access to credit from banks and MFIs. First, determinants of access to Bank 
finance were identified in table 3 and table 4 below. The Omnibus Tests of Model Coefficients gives an overall indication of how well the model performs, over and above the results obtained when none of the predictors are entered into the model. This is referred to as a 'goodness of fit' test. For this set of results, we want a highly significant value. The omnibus test of the model coefficient for this specific study is given in table 3 below.

Table 3. Omnibus Test.

\begin{tabular}{lllll}
\hline & & Chi-square & Df & Sig. \\
\hline \multirow{3}{*}{ Step 1 } & Step & 52.303 & 10 & .000 \\
& Block & 52.303 & 10 & .000 \\
& Model & 52.303 & 10 & .000 \\
\hline
\end{tabular}

Table 3 above shows that when all ten predictor variables are considered all together, they significantly predict whether or not a firm can access credit from bank at $\chi 2=52.303, d f=$ $10, N=200, P=.000$. The effect of the specific factors on access to bank finance is presented in table 4 below.

Table 4. Logistic Regression Result.

\begin{tabular}{lllll}
\hline Factors & B & SE & Wald & Sig \\
\hline ENT & .412 & .671 & .378 & .539 \\
ACCT & .873 & 1.274 & .470 & .493 \\
COL & 2.100 & .761 & 7.618 & .006 \\
MAGE & .146 & .084 & 3.012 & .083 \\
SEC & -.693 & .338 & 4.190 & .041 \\
LEG & 1.307 & .642 & 4.146 & .042 \\
OAGE & .093 & .047 & 3.897 & .048 \\
EXP & -.136 & .092 & 2.197 & .138 \\
REL & -1.365 & .845 & 2.609 & .100 \\
SIZE & .099 & .045 & 4.842 & .028 \\
Constant & -6.608 & 2.461 & 7.211 & .007 \\
\hline
\end{tabular}

From table 4 , it can be seen that availability of collateral, MSE's age, Sector, Legal ownership, owner's/manager's age, owner's/manager's religion and Size of the MSE significantly determine access to bank credit at $p<0.1$. Other variables including entrepreneur capability of the owner or manager, keeping accounting record, experience of the owner or manager are not found to determine access to bank credit significantly.

In addition to access to bank credit, the following table 5 and table 6 identify factors that determine access of credit from MFIs.

Table 5. Omnibus Test.

\begin{tabular}{lllll}
\hline & & Chi-square & Df & Sig. \\
\hline \multirow{3}{*}{ Step 1 } & Step & 28.187 & 10 & .002 \\
& Block & 28.187 & 10 & .002 \\
& Model & 28.187 & 10 & .002 \\
\hline
\end{tabular}

Table 5 above shows that when the ten predictor variables are considered all together, they significantly predict whether or not a firm can access credit from MFIs at $\chi 2=28.187, d f=$ $10, N=200, P=.002$. The effect of the specific factors on access to MFI credit is presented in table 6 below.
Table 6. Logistic Regression Result.

\begin{tabular}{lllll}
\hline & B & S. E. & Wald & Sig. \\
\hline ENT & .363 & .419 & .748 & .387 \\
ACCT & 1.443 & .657 & 4.824 & .028 \\
COLL & -.439 & .607 & .523 & .469 \\
MAGE & .057 & .071 & .648 & .421 \\
SEC & -.336 & .184 & 3.330 & .068 \\
LEG & .832 & .478 & 3.026 & .082 \\
OAGE & .074 & .034 & 4.747 & .029 \\
EXP & -.104 & .065 & 2.550 & .100 \\
REL & -.318 & .453 & .493 & .482 \\
SIZE & -.101 & .062 & 2.679 & .100 \\
Constant & -4.410 & 1.652 & 7.124 & .008 \\
\hline
\end{tabular}

From table 6, it can be seen that Keeping accounting record, Sector, Legal status, owner's/manager's age, owner's/manager's business experience and Size of the MSE significantly determine access to credit from MFIs at $p<0.1$. Other variables including entrepreneur capability of the owner or manager, availability of collateralized asset, MSE's age, and owner's or manager's religion are not found to determine access to credit from MFIs.

From table 4 and table 6 , the four common independent variables that significantly determine access to finance from Banks and MFIs are sector in which the MSE is engaged, legal status of the MSE, age of the owner or the manager of the MSE and size of the MSE. These common factors are discussed in detail with respect to the literature in the following paragraphs.

The two logistic regressions found that sector in which the MSE is engaged significantly affect access to formal external financial sources at a significant level of $\mathrm{P}<0.1$. This implies, MSEs engaged in manufacturing and construction sector easily access credit from banks and MFIs as compared to those engaged in trading and service sector. One reason for this might be; those in the manufacturing and construction sector tend to have more fixed assets which can be used as collateral for obtaining credit. Another reason might be, those MSEs in manufacturing and construction are governments propriety area and Financial institutions particularly MFIs can render the required amount to them. The same finding was obtained in a study in Zinbabewe by Martin and Daniel [30]. Kebede, Tirfe \& Abera have also found positive relationship between sector and access to formal financial sources though the value is not statistically significant [25].

Another independent variable that significantly determines access to formal finance is legal form of the MSE at a significant level of $\mathrm{P}<0.1$. This implies MSEs with legal status of PLC and Partnership tend to have more access to formal finance as compared to sole proprietorship. This might be because PLCs and partnerships have more capital that can serve as collateral as compared to sole proprietorship and banks and MFIs can easily grant credit to them. Similar to this finding, Gebru found the probability that MSEs preferring external finance is 5.8 times higher for partnership businesses compared to sole proprietorship businesses. Similarly, the probability that MSEs that are established as PLC prefer external finance is 8.9 times that of sole proprietorships [20]. 
The variable owner's or manager's age has a positive and statistically significant effect on MSE's access to credit from formal financial institutions at $\mathrm{P}<0.1$ level of significance. This indicates that owners or managers with older age are more likely to access credit from formal financial institutions than those with younger age. This implies that the personal financing preferences of owners or managers appear to change according to age and the age of the entrepreneur is a significant determinant of the risk of borrowing. In line with this other researchers also argue that as the age of the owner or manger increases, so does his business experience, practical, wisdom and his income generating capacity. In addition, due to capability of the older entrepreneurs to accumulate assets which are used as collaterals, formal financial institutions perceive them as creditworthy. As a result, they are more likely to access credit from formal financial institutions than the younger counterpart. This result is consistent with previous study of Anthony et al. [4] but contrary to the study of Sabopetji and Belete [45].

Size of the MSE is another factor that has a positive and significant effect on MSEs' access to credit from formal financial institutions at $\mathrm{P}<0.1$ level of significance. This means that compared to MSEs with large size, MSEs with small size are less likely to access credit from formal financial institutions. This result is consistent with previous studies of Cassar and Gebru [13] [20]. In addition, World Bank survey confirmed that large firms everywhere generally have more access to bank credit than small firms [16]. Formal credit is out of reach for smaller enterprises and compared to large firms, smaller firms face a relative disadvantage to raise finance from formal institutions such as banks because they are considered to have higher financial risk [20].

In addition to the above demand side factors, the descriptive survey and the interview with managers of financial institutions working in the three towns indicated that, loan procedures and high interest rate charged by the FIs determine access to formal finance by MSEs. Recognizing these impediments, recently OCSSCO, one of the dominant FIs operating in the region has improved the forced saving requirement from $20 \%$ to $5 \%$ and has improved the group loan and guarantee procedures. Location of the MFIs is not identified as a problem since all of the MSEs surveyed are found in the towns and at the moment at least one MFIs is available in each towns throughout the country.

\section{Conclusion}

From the analysis, it was seen that availability of collateral, MSE's age, Sector of the MSEs, Legal ownership, owner's or manager's age, owner's or manager's religion and Size of the MSE significantly determine access to bank credit at $\mathrm{p}<0.1$. Other variables including entrepreneur capability of the owner or manager, keeping accounting record, experience of the owner or manager are not found to determine access to bank credit. It was also seen that Keeping accounting record,
Sector, Legal ownership, owner's or manager's age, owner's or manager's business experience and Size of the MSE significantly determine access to credit from MFIs at $p<0.1$. The remaining variables including entrepreneur capability of the owner or manager, availability of collateralized asset, MSE's age, and owner's or manager's religion are not found to determine access to credit from MFIs. From suppliers side, loan procedure and high interest rate charged by FIs are the main problems that hinder MSEs from accessing formal credit.

The four common independent variables that significantly determine access to finance from Banks and MFIs are sector in which the MSE is engaged, legal status of the MSE, age of the owner or the manager of the MSE and size of the MSE. This implies that though MFIs are established to provide credit to MSEs, the system of credit provision is almost similar with banks. Both of these financial institutions need to make sure that the credit granted should be collected back. This further implies that MFIs do not want to take some sort of credit risk similar to their bank counterpart. From supply side, high interest rate and long loan procedures are the main factors affecting access to finance to formal sources.

\section{References}

[1] Abdullah, M. A., \& Manan, S. K. (2011). Small and Medium Enterprises and their Financing Patterns: Evidence from Malaysia. Journal of Economic Cooperation and Development, $32(2), 1-18$.

[2] Abor, J., \& Biekpe, N. (2007). Small Business Reliance on Bank Financing in Ghana. Emerging. Mark. Financ. Trade, 43 (4), 93-102.

[3] Abor, J. (2008). Determinants of the Capital Structure of Ghanaian firms. African Economic Research Consortium.

[4] Anthony, K. A., \& Frank, G. S. (2013). Determinants of credit rationing to the private sector in Ghana. African Journal of Business Management, 7 (38), 3864-3874.

[5] Ayalew, B. B., \& Gashu M. (2015). Factors affecting access to finance with reference to MSE in Dilla town, Ethiopia. Journal for studies in management and planning.

[6] Beck, T., Demirgüç-Kunt, A., \& Maksimovic, V. (2008). Financing patterns around the world: Are small firms different? Journal of Financial Economics, 89 (3), 467-487, doi: http://dx.doi.org/10.1016/j.jfineco.2007.10.005

[7] Berger, A. N., \& Udell, G. F. (1998). The economics of small business finance: The roles of private equity and debt markets in the financial growth cycle. Journal of Banking \& Finance, 22, 613-673.

[8] Bigsten, A. et. al (2003). Credit Constraints in Manufacturing Enterprises in Africa. Journal of African Economies, 12 (1), 104-125. doi: http://dx.doi.org/10.1093/jae/12.1.104

[9] Brooks, A., Collings, S. \& Gonzales, P. (1990). Accounting for Small Business: a Single-Entry Approach, VCTA Publishing, Collingwood. 
[10] Briozzo \& Vigier (2009). The effect of life cycles on diversification of financing sources for SMEs: Evidence from Argentina. African Journal of Business Management, 6 (3), 811-826.

[11] Byron, E. L., \& Friedlob, G. T. (1976). Why small businesses fail, Management Accounting.

[12] Bhaird, C., \& Lucey, B. (2010). Determinants of capital structure in Irish SMEs. Small Business Economics, 35, 357 375 .

[13] Cassar, G. (2004). The Financing of business start-ups. Journal of Business Venturing. 19, 261-283.

[14] Cole, R. A. (1998). The Importance of Relationships to the Availability of Credit. Journal of Banking and Finance, 22 (6), 959-977. http://dx.doi.org /10.1016/S0378-4266(98)00007-7

[15] Commercial code. (1960). Commercial code of Imperial Government of Ethiopia. Addis Ababa: Berhanena Selam Printing Enterprise.

[16] Cull, R., Davis, L. E., Lamoreaux N. R., \& Rosenthal J. (2005). Historical financing of small and medium size enterprises. World Bank Policy Research Working Paper No. 2334 .

[17] Fanta, A. B. (2012). Banking reform and SME financing in Ethiopia: Evidence from manufacturing sector. African Journal of Business Management, 6 (19), 6057-6069.

[18] Fatoki, O. O., \& Asah, F. (2011). The Impact of Firm and Entrepreneurial Characteristics on Access to Debt Finance by SMEs in King Williams' Town, South Africa. International Journal of Business and Management, 6 (8), p 170. http://dx.doi.org/:10.5539/ijbm.v6n8p170

[19] Frempong, G. (2007). Towards an African e-Index: Small \& Medium Business Survey Wireless Opportunities and Solutions: A regulatory perspective LIRNE Expert Meeting and International Workshop, 7-9.

[20] Gebru, G. H. (2009). Financing preferences of micro and small enterprise owners in Tigray: does POH hold? Journal of Small Business and Enterprise Development, 16 (2) 322 334.

[21] Gujarati, D. N. (2003). Basic econometrics ( $4^{\text {th }}$ ed.). USA, Mc Graw-Hill.

[22] Honhyan, Y. (2009). The determinants of capital structure of the SMEs: An empirical study of Chinese listed manufacturing companies. Journal of Finance and Economics. 77, 117-146.

[23] Hutchinson, P. (1999). Small Enterprise: Finance, Ownership and Control. International Journal of Management Reviews, 1 (3), 343-365. http://dx.doi.org/10.1111/1468-2370.00018

[24] Jordan, J., Lowe, J., \& Taylor, P. (1998). Strategy and financial policy in UK small firms. Journal of Business Finance and Accounting, 25 (1), 1-27.

[25] Kebede, S. N., Tirfe, A. G. \& Abera, N. (2014). Determinants of MSEs' access to finance. Developing countries studies. 4 (21).

[26] Kothari, C. R. (2004). Research methodology: Methods and techniques $\left(2^{\text {nd }}\right.$ Rev. ed.). New Delhi, New age International publishers.
[27] Kroszner, R. S. (2003). What drives productivity growth? Implication for the economy and Prospects for the future.

[28] Klapper, L., Sarria, A. V., \& Sulla. (2002). Small and medium size enterprise financing in Eastern Europe. Working Paper.

[29] Linder, B., \& Hoelzl, K. (2012). SME financial reporting practice in Austria. World Bank center for financial reporting reform (CFRR) and the Austrian Institute of for SME Research.

[30] Levitsky, J., \&. Prasad, R. (1989), Credit guarantee schemes for small and medium enterprises. World Bank technical paper; no. 58. World Bank, Washington DC.

[31] Martin, M. M., \& Daniel, K. T. (2013). Does Firm Profile Influence Financial Access Among Small And Medium Enterprises In Kenya? Asian Economic and Financial Review. 3 (6): 714-723.

[32] Mateev, M., Poutziouris, P., \& Ivanov, K. (2013). On the determinants of SME capital structure in Central and Eastern Europe: A dynamic panel analysis. Research in International Business and Finance, 27 (1), 28-51. doi: http://dx.doi.org/10.1016/j.ribaf.2012.05.002

[33] McMahon, R. G. P., and Holmes, S. (1991). Small business financial management practices in North America: A literature review, Journal of Small Business Management, $19-28$.

[34] Michaelas, N., Chittenden, F., \& Poutziouris, P. (1999). Financial Policy and Capital Structure Choice in U.K. SMEs: Empirical Evidence from Company Panel Data. Small Business Economics, 12 (2), 113-130. http://dx.doi.org/10.1023/A:1008010724051

[35] Mosisa, T. (2011). Accounting practices of small and medium sized enterprises and its effect on access to finance in Addis Ababa (MSc thesis) AAU.

[36] Mulaga, A. N. (2013). Analysis of External Financing Use: A Study of Small and Medium Enterprises in Malawi. International Journal of Business management. 8 (7).

[37] McMahon, R. G. P., and Holmes, S. (1991). Small business financial management practices in North America: A literature review, Journal of Small Business Management, 19-28.

[38] Odit, M. P., \& Gobardhun, Y. D. (2011). The determinants of financial leverages of SME are in Mauritius. Int. Bus. Econ res. $J, 10,113-125$.

[39] Okpara, J., \& Wynn, P. (2007). Determinants of Small Business Growth Constraints in a Sub- Saharan African Economy. South Africa: Sam Publication.

[40] Ono, A., \& Uesugi, I. (2009). Role of Collateral \& personal Guarantees in relationship lending: evidence from Japan's SME Loan Market. Journal of Money credit \& market.

[41] Pallant, J. (2005). SPSS Survival manual: A step by step guide to data analysis using SPSS for window (Version 12). Australia, Allen \& Unwin.

[42] Petersen, M. A., \& Rajan, R. G. (1994). The Benefits of Lending Relationships: Evidence from Small Business Data. The Journal of Finance, 49 (1), 3-37. doi: http://dx.doi.org/10.2307/2329133

[43] Quartey, P. (2003). Financing Small and Medium Enterprises (SMEs) in Ghana. Journal of African business, 4 (1), $37-55$. 
[44] Reddy, M. (2007). Small Business in Small Economies: Constraints and Opportunities for Growth. Social and economic studies, 56 (1/2), 304-321.

[45] Romano, C., Tanewski, G. \& Smyrnios, K. (2001). Capital Structure Decision Making: A Model for Family Business. Journal of Business Venturing, 16 (3), 285-310.

[46] Sebopetji, T. O., Belete, A. (2009). An Application of Probit Analysis to Factors Affecting Small-Scale Farmers Decision to take Credit: a Case Study of Greater Letabo Local Municipality in South Africa. African Journal of Agricultural Research. 4 (8), 718-723.

[47] Ssendaula, G, (2002). Minister of Finance, Planning and Economic Development, Keynote Address on a Symposium on "Modalities for Financing Small and Medium-Scale Enterprises", United Nations.

[48] Storey, D., (1994). Understanding the Small Business Sector, Routledge, London, 33-55.
[49] Stevens, J. (1996). Applied multivariate statistics for the social science (3rd ed.). USA, Lawrence Erlbaum.

[50] Tabachnick, B. G., \& Fidell, L. S. (2007). Using multivariate statistics. USA: Pearson Education, Inc.

[51] Van Auken, H. (2005). Differences in the usage of bootstrap financing among technology-based vesus non-technologybased firms. Journal of Small Business Management, 43 (1), 93-103.

[52] Van der wijst. (1989). Determinants of Small Firm Debt Ratios: An Analysis of Retail Panel Data. Small Business Economics, 5, 55-65.

[53] Vos, E., Yeh, A. J, Carter, S., \& Tagg, S. (2007). The happy story of small business financing. Journal of Banking \& Finance, $31 \quad$ (9), 2648-2672. doi: http://dx.doi.org/10.1016/j.jbankfin.2006.09.011 